\title{
Circulation of the Cultivable Symbiont Serratia symbiotica in Aphids Is Mediated by Plants
}

\author{
Inès Pons*, François Renoz, Christine Noël and Thierry Hance \\ Earth and Life Institute, Biodiversity Research Centre, Université catholique de Louvain, Louvain-la-Neuve, Belgium
}

\section{OPEN ACCESS}

Edited by:

Ana E. Escalante,

National Autonomous University of Mexico, Mexico

Reviewed by: Frédérique Reverchon,

Instituto de Ecología (INECOL), Mexico

Edgardo Sepulveda, Ensenada Center for Scientific Research and Higher Education (CICESE), Mexico

${ }^{*}$ Correspondence: Inès Pons

ines.pons@uclouvain.be

Specialty section:

This article was submitted to Microbial Symbioses, a section of the journal Frontiers in Microbiology

Received: 10 January 2019 Accepted: 26 March 2019 Published: 15 April 2019

Citation:

Pons I, Renoz F, Noël $C$ and Hance T (2019) Circulation of the

Cultivable Symbiont Serratia symbiotica in Aphids Is Mediated by Plants. Front. Microbiol. 10:764. doi: 10.3389/fmicb.2019.00764
Symbiosis is a common phenomenon in nature that substantially affects organismal ecology and evolution. Fundamental questions regarding how mutualistic associations arise and evolve in nature remain, however, poorly studied. The aphid-Serratia symbiotica bacterium interaction represents a valuable model to study mechanisms shaping these symbiotic interspecific interactions. S. symbiotica strains capable of living independently of aphid hosts have recently been isolated. These strains probably resulted from horizontal transfers and could be an evolutionary link to an intra-organismal symbiosis. In this context, we used the tripartite interaction between the aphid Aphis fabae, a cultivable S. symbiotica bacterium, and the host plant Vicia faba to evaluate the bacterium ability to circulate in this system, exploring its environmental acquisition by aphids and horizontal transmission between aphids via the host plant. Using molecular analyses and fluorescence techniques, we showed that the cultivable S. symbiotica can enter the plants and induce new bacterial infections in aphids feeding on these new infected plants. Remarkably, we also found that the bacterium can have positive effects on the host plant, mainly at the root level. Furthermore, our results demonstrated that cultivable S. symbiotica can be horizontally transferred from infected to uninfected aphids sharing the same plant, providing first direct evidence that plants can mediate horizontal transmission of certain strains of this symbiont species. These findings highlight the importance of considering symbiotic associations in complex systems where microorganisms can circulate between different compartments. Our study can thus have major implications for understanding the multifaceted interactions between microbes, insects and plants.

Keywords: horizontal transfers, environmental acquisition, plant-mediated transmission, insect-microbe associations, trophic networks

\section{INTRODUCTION}

Symbiotic associations are widespread in nature and can take different forms. Some symbiotic microorganisms are harmful (parasites), while others can be beneficial for their hosts (mutualists) (Kikuchi and Fukatsu, 2014). These interactions are, however, not fixed and can evolve along a symbiotic continuum depending on the environment in which they live (Parmentier and Michel, 2013; Sánchez et al., 2016). Symbioses occur among a wide range of organisms, with insects comprising the largest group (Kikuchi et al., 2007). In general, insects that feed on a nutritionally 
limited diet, such as plant sap or blood, have to deal with the lack of some essential nutrients (Frago et al., 2012). The association with mutualistic obligate symbionts that complement the host insect with these essential nutrients has allowed these organisms to access otherwise unusable resources and to evolve as complex entities (Buchner, 1965; Baumann, 2005; Dale and Moran, 2006; Gündüz and Douglas, 2009; Snyder et al., 2010; Vigneron et al., 2014). Symbiotic bacteria can thus play a crucial role in the evolution and ecology of their hosts by bringing new beneficial biological properties, while at the same time benefiting from food, means of dispersal or multiplication (Duron and Hurst, 2013; Oliver et al., 2014). Explaining how these associations are formed and spread through insect populations remains one of the most fundamental questions within the field of symbiosis research.

To ensure the fixation and persistence of such symbiotic associations, various sophisticated mechanisms of transmission may take place (Bright and Bulgheresi, 2010; Salem et al., 2015). Vertical transfer of symbionts from parent to offspring is one important way by which beneficial associations can be maintained (Salem et al., 2015). Transmission processes may differ between obligate and facultative symbionts (Kikuchi et al., 2007). Obligate associations such as tsetse flies-Wigglesworthia glossinidia and aphids-Buchnera aphidicola show host-symbiont phylogenetic congruence, suggesting evolutionary ancient and stable associations are maintained by a strict vertical transmission (Moran et al., 1993; Clark et al., 2000; Wernegreen, 2002). In contrast, in facultative associations, symbiont phylogeny rarely reflects host phylogeny, suggesting that the symbiont can also experience occasional horizontal transfers (Sandström et al., 2001; Clayton et al., 2012; Gehrer and Vorburger, 2012). Stable symbiotic associations without vertical transmission are, however, also found in nature as shown by associations between bean bugs and Burkholderia or between squids and Vibrio (Schultze and Kondorosi, 1998; Nyholm and McFall-Ngai, 2004; Kikuchi et al., 2007; Caspi-Fluger et al., 2012; Gonella et al., 2015). Life in symbiosis is not required for these microorganisms and a free-living population may serve as the inoculum for the emergence of symbiosis (Bright and Bulgheresi, 2010; McFrederick et al., 2017).

Aphids (Hemiptera: Aphididae) represent a valuable model to study the mechanisms involved in symbiont transmissions. Aphids typically harbor an obligate symbiont that provides essential amino acids that are deficient in plant phloem on which aphids feed (Douglas, 1998), but aphids can also harbor a wide variety of facultative symbionts (Oliver et al., 2010), known to be associated with benefits to aphid hosts (Montllor et al., 2002; Oliver et al., 2003; Scarborough et al., 2005; Burke et al., 2009; Tsuchida et al., 2010; Simon et al., 2011). Serratia symbiotica is one of the most frequent facultative symbionts of aphids (Henry et al., 2015). This species in particular is of interest, because it includes different strains associated with very distinct biological characteristics. In the Lachninae subfamily, S. symbiotica supplements the metabolic abilities of Buchnera aphidicola for tryptophan synthesis and has been depicted as a co-obligate partner (Gosalbes et al., 2008; Lamelas et al., 2011), whereas in the aphid Acyrthosiphon pisum, S. symbiotica is a facultative endosymbiont generally associated with heat stress tolerance and parasitoid resistance for its host (Oliver et al., 2003; Burke et al., 2009). In addition, some S. symbiotica strains have been isolated from aphids in the genus Aphis and cultivated freely on a pure artificial medium (Sabri et al., 2011; Grigorescu et al., 2017). These strains represent the only symbiotic bacteria of aphids that has successfully been reared in pure culture (Sabri et al., 2011), suggesting that they potentially can live in a simple environment independently of an insect host. The absence of an interdependence with aphid hosts, as well as genomic features, suggest that cultivable $S$. symbiotica strains are involved in the early stages of symbiosis with aphids, having diverged little from their free-living counterparts (Manzano-Marín et al., 2016; Renoz et al., 2017). A new study further revealed that these cultivable S. symbiotica strains would reside naturally in the aphid guts (Renoz et al., 2018), contrary to what is generally observed with this endosymbiont. Taken together, these results suggest that these S. symbiotica strains may potentially serve as an environmental reservoir for symbiotic bacteria acquisition. It is therefore critical to understand how these cultivable S. symbiotica strains circulate in the environment to decipher their acquisition route and their possible horizontal transmission.

Infections through the environment could provide new beneficial traits to aphid hosts creating a pathway for the emergence of new symbiotic associations. Although no study has shown the presence of S. symbiotica bacteria freely in the environment, it is well known that bacteria of the Serratia genus are capable to grow in a variety of environments, such as animals, soil and plants, including phytopathogens, as well as mutualists improving the health and development of their host plants (Petersen and Tisa, 2013). In a recent study, we showed that the cultivable S. symbiotica $\left(\mathrm{CWBI}-2.3^{\mathrm{T}}\right)$ can be either beneficial or parasitic for its aphid hosts depending on the ecological context and we also presented evidence that this cultivable S. symbiotica is extracellularly transmitted to future generations, potentially via contamination with honeydew (Pons et al., 2019). Nevertheless, the ability of the cultivable strain to colonize plants as well as, its biological effects on infected plants are currently unknown. Moreover, given that cultivable S. symbiotica is potentially located in the aphid gut, the plant may well be another source of transfer. Indeed, the role of plants in insect symbionts transmission is attracting more and more attention (Caspi-Fluger et al., 2012; Gonella et al., 2015; Li et al., 2018). Nonetheless, although phylogenetic analyses suggest some horizontal transfers or repeated infections from an exogenous source (Sandström et al., 2001; Darby and Douglas, 2003; Russell et al., 2003), there is little direct evidence that host plants can mediate horizontal transfers of aphid symbionts. The cultivable S. symbiotica are thus of great interest to study horizontal transmissions of aphid symbionts.

To gain insight into the circulation of the cultivable S. symbiotica bacterium (CWBI- $2.3^{\mathrm{T}}$ ) between the aphid Aphis fabae and the host plants Vicia faba, we experimentally investigated whether cultivable S. symbiotica was able to transit from the soil to the plants, and then be acquired by aphids feeding on these plants. We also analyzed the biological effects of the bacterium on host plants. In addition, we studied whether host plants can mediate horizontal transfers of cultivable 
S. symbiotica strain between aphids. Overall, our study highlights the importance to consider symbiosis in complex systems, where bacteria can circulate between different partners.

\section{MATERIALS AND METHODS}

\section{Insects Rearing and Bacterial Strains}

The clone A06-407 of A. fabae used in this study was originally collected from Chenopodium album in St. Margrethen (Switzerland) and provided by Dr. Christophe Vorburger (University of Zurich) (Vorburger and Gouskov, 2011). The clone was found to be uninfected with any known facultative symbiont of aphids (Vorburger et al., 2009; Vorburger and Gouskov, 2011). Insects were reared on seedlings of $V . f a b a$ at $18^{\circ} \mathrm{C}$ in a longday regimen ( $16 \mathrm{~h}$ light, $8 \mathrm{~h}$ dark) and $65 \pm 3 \%$ of humidity to ensure parthenogenetic reproduction. The cultivable CWBI- $2.3^{\mathrm{T}}$ S. symbiotica strain was used in this study. The bacterium was isolated from a natural A. fabae collected in Belgium (Sabri et al., 2011). Bacteria were preserved in frozen stocks at $-80^{\circ} \mathrm{C}$ and cultured at $20^{\circ} \mathrm{C}$ with 863 medium ( $1 \%$ yeast extract, $1 \%$ casein peptone, $1 \%$ glucose) as described in (Sabri et al., 2011).

\section{Diagnostic PCR}

Diagnostic PCR was used to check the integrity of the A. fabae population before experiments and to determine the presence of cultivable S. symbiotica in aphids and $V$. faba plants after infection. DNA from individual aphids was extracted by using a high salt-extraction method (Aljanabi and Martinez, 1997) and DNA from part of plants was extracted by using the CTAB method (Doyle, 1991). PCR primers used for S. symbiotica detection were 16SA1 (5'-AGAGTTTGATCMTGGCTCAG-3') and PASScmp (5'-GCAATGTCTTATTAACACAT-3') (Fukatsu et al., 2000). PCR reactions were performed in a final volume of $15 \mu \mathrm{l}$ containing $1 \mu \mathrm{l}$ of the template DNA lysate, $0.5 \mu \mathrm{M}$ of each primer, 200- $\mu \mathrm{M}$ dNTP's, $1 \mathrm{X}$ buffer and 0.625 unit of Taq DNA polymerase (Roche). The PCR reaction conditions consisted of 35 cycles at $95^{\circ} \mathrm{C}$ for $30 \mathrm{~s}, 55^{\circ} \mathrm{C}$ for $1.5 \mathrm{~min}$ and $72^{\circ} \mathrm{C}$ for $1.5 \mathrm{~min}$. DNA from an infected line of the aphid A. pisum was used as a positive control [Tucson clones by the Nancy Moran Lab (Burke et al., 2009)]. The amplicons were then purified and sequenced in both directions (Macrogen Inc., Amsterdam). The resulting sequences were cleaned and aligned using Geneious ${ }^{\circledR}$ v9.1.5 (Kearse et al., 2012) and compared to sequences on GenBank using BLAST to verify the identity of recovered S. symbiotica in aphids and plants (similarity threshold $=100 \%$ ).

\section{Bacterial Solution and Aphid Oral Infection}

A cultivable $S$. symbiotica solution was prepared and used to infect aphids and host plants. The bacteria were first grown to an early log phase in 863 medium (without antibiotic) (Sabri et al., 2011) on a gyratory shaker $(160 \mathrm{rpm})$ at $20^{\circ} \mathrm{C}$. When an optical density (OD) between 0.5 and 0.7 at $600 \mathrm{~nm}$ was reached during the logarithmic growth phase, bacteria were centrifuged. The bacterial cells were then washed with sterile PBS (Sigma), suspended in buffer and adjusted to obtain a bacterial solution with an $\mathrm{OD}$ of 1 at $600 \mathrm{~nm}$. Oral infection was performed by feeding aphids on an artificial medium containing the bacterial solution to insure presence of the bacterium in the digestive tract of the new host (Altincicek et al., 2011). To standardized aphids, adult females of $A$. fabae were left on young $V$. faba plants during $24 \mathrm{~h}$ to produce nymphs. After removal of adult insects, newborn nymphs were kept on the same plants for 4 days prior to infection experiments. Third-instar aphid nymphs were then fed on an artificial diet (Cambier et al., 2001) for $24 \mathrm{~h}$. One hundred $\mu \mathrm{l}$ of bacterial solution (only sterile PBS for the control treatment) was mixed with $20 \mathrm{ml}$ aphid diet [corresponding to approximately $10^{6} \mathrm{CFU} / \mathrm{ml}$ of diet; as found in (Darby and Douglas, 2003; Altincicek et al., 2011; Renoz et al., 2015)]. Diagnostic PCR was carried out on some aphids to verify that these ones were infected by the bacteria.

\section{Environmental Acquisition Experiment}

To study the environmental acquisition of the cultivable S. symbiotica by aphids, an experiment was carried out via a plant watering system with a bacterial solution. It consisted of mixing $7 \mathrm{ml}$ of the solution of cultivable S. symbiotica or PBS (control) in one liter of 863 medium (corresponding to approximately $10^{6} \mathrm{CFU} / \mathrm{ml}$ of solution). The mixture was placed on gyratory shaker $(160 \mathrm{rpm})$ at $20^{\circ} \mathrm{C}$ allow bacterial growth. After 1 day, each young plant (reared during 20 days at $20 \pm 2{ }^{\circ} \mathrm{C}$ under a long day regimen ( $16 \mathrm{~h}$ light, $8 \mathrm{~h}$ dark) and $65 \pm 3 \%$ of humidity) was watered with $200 \mathrm{ml}$ of the mixture. Six trays were used for the bacterial infection condition and two trays for the control condition (Figure 1A). In each tray, two plants (one for each survey) were used to analyze the bacterial acquisition by plants and on two others plants treated in the same way, ten aphids were placed per plant to analyze aphid bacterial acquisition (Figure 1A). After 3 and 7 days of exposure, three portions (two pieces of leaves (one on each leaf), two pieces of stems and two pieces of roots) of each plant were collected and all aphids sampled. For each survey, six replicates for the bacterial infection condition and two replicates for the control condition were performed (five to nine aphids per plant and one plant per replicate). All the material was then analyzed for the presence of S. symbiotica by diagnostic PCR.

\section{Plant Measurement}

To investigate the biological effects of the cultivable S. symbiotica on host plants, we measure eight plant functional traits (Kraft et al., 2015): maximum shoot length (cm), maximum root length $(\mathrm{cm})$, total leaf dry mass $(\mathrm{g})$, total leaf area $\left(\mathrm{cm}^{2}\right)$, total root dry mass (g), specific leaf area (SLA, $\mathrm{cm}^{2} / \mathrm{g}$ ) defined as the ratio of total leaf area to total leaf dry mass (Wright and Westoby, 1999), specific root length (SRL, cm/g) defined as the ratio of root length to total root dry mass (Wright and Westoby, 1999) and root:shoot ratio. These traits are known to capture ecologically significant variation in leaves, roots and whole-plant function across plant species (Kraft et al., 2015). Trait measurements were performed on young plants aged 20 days, having been exposed to the plant watering system, as explained previously (Figure 1A). Whole plants were photographed using a camera (Canon EOS 450D 


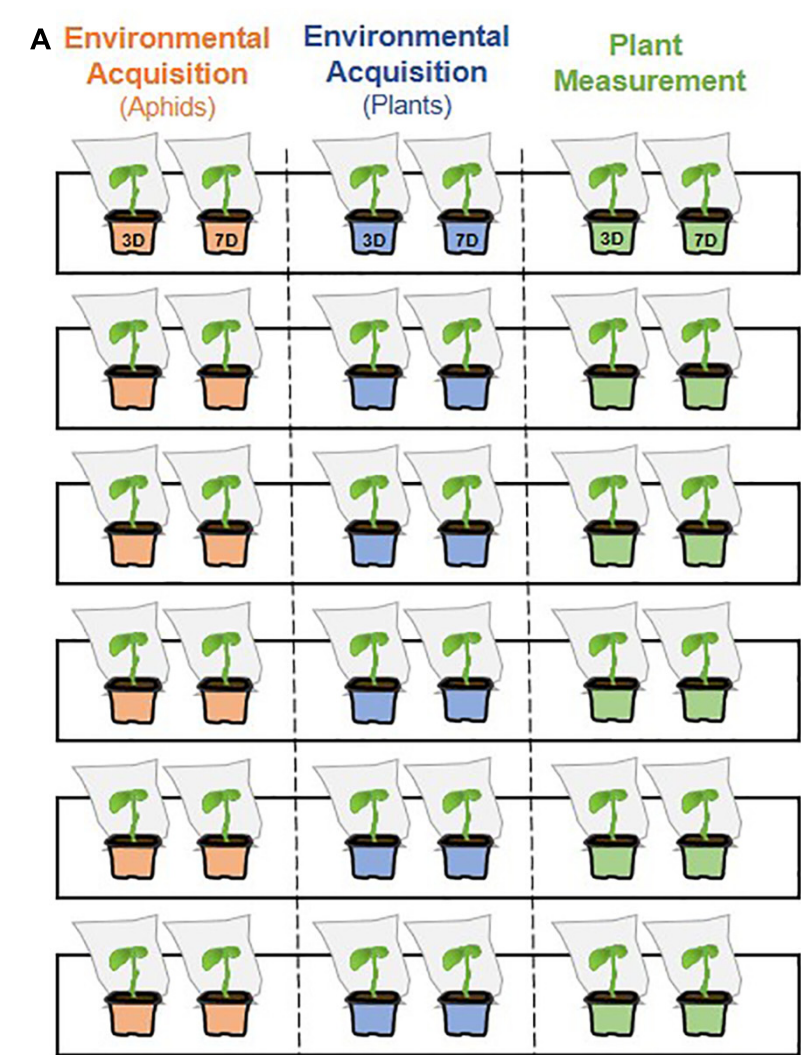

Watering plants with a bacterial solution

\section{B Horizontal Transmission}

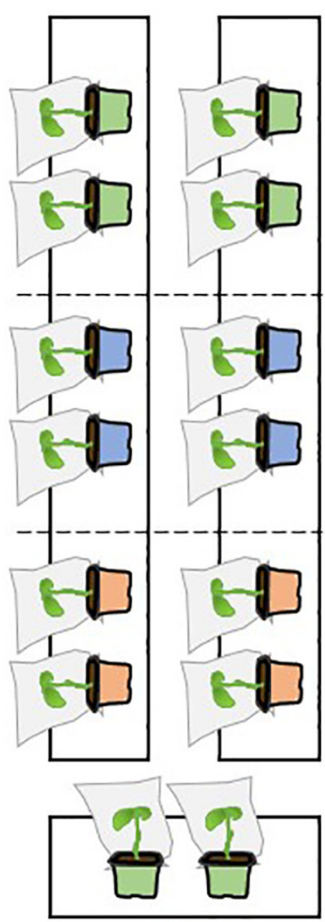

Control

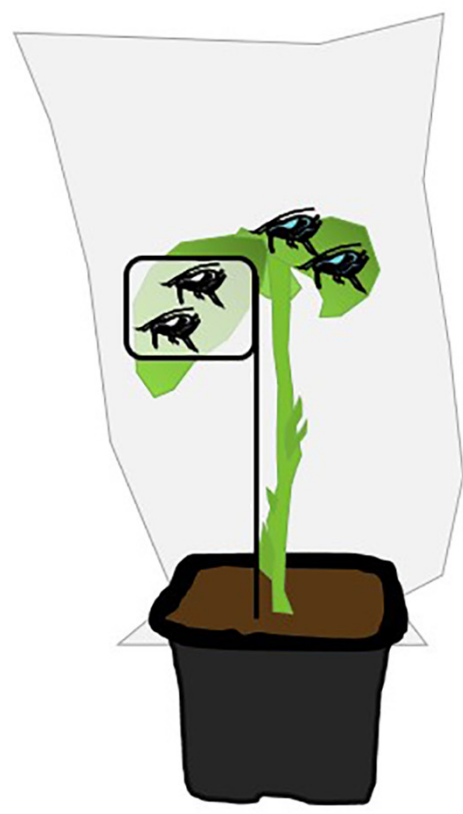

FIGURE 1 | Schematic overview of environmental acquisition, plant measurement (A) and horizontal transmission (B) experiments. (A) Six trays were used for the bacterial infection condition and two trays for the control condition (three for the plant measurement experiment). In each tray, two plants were used to analyze the aphid bacterial acquisition (orange), two others plants were used to analyze the bacterial acquisition by plants (blue) and two others plants were used to measure plant functional traits (green). Two surveys were conducted: 3D =3-days acquisition duration and 7D = 7-days acquisition duration. (B) Six to fifteen uninfected aphids (white gut) were placed inside the leaf cage on the plant and another 15 infected aphids (blue gut) were placed outside from the leaf cage, allowing the release of the bacterium on plant tissues (uninfected aphids for the control).

Zoom EFS 18-55 mm). Measurements of maximum shoot length, maximum root length and total leaf area were then performed using ImageJ's measuring function (Abramoff et al., 2004). All fresh leaves and roots of each plant were dried to a constant mass at $60^{\circ} \mathrm{C}$ and weighed on an analytical balance (Ohaus Explorer E12140, Switzerland). Weight measurement allowed us to determine the SLA and the SRL. The root:shoot ratio was also measured using the total root dry mass to the total leaf dry mass. After 3 and 7 days of exposure, each plant was used for the measurements, after gently washing of its root to remove the soil. For each survey, 3 replicates for the control condition and 6 replicates for the bacterial infection condition were performed (1 plant per replicate).

\section{Horizontal Transmission Test}

To determine whether the cultivable S. symbiotica bacterium is capable of horizontal transfers between aphids via plant sap, feeding experiments on $V$. faba plants were performed. Six to fifteen uninfected third instar aphids were placed inside a leaf cage attached on a young $V$. faba plant to prevent nymphs escaping and contamination via honeydew (Figure 1B; Caspi-Fluger et al., 2012). Another fifteen third instar aphids infected by the bacterium were placed outside from the leaf cage, allowing the release of the bacterium on plant tissues (Figure 1B). A diagnostic PCR was carried out on the aphids placed in cages after 3 and 7 days as described in (Gonella et al., 2015) to test for the presence of $S$. symbiotica (4 replicates/survey). Negative controls followed the same protocol, but the uninfected aphids were exposed to uninfected aphids (3 replicates/survey).

The same procedure was used to test for the presence of cultivable $S$. symbiotica in leaves placed inside leaf cages and thus to study the efficiency of cultivable S. symbiotica bacteria transmission from aphids to plants (3 replicates/survey for the infected plants and 1 replicate/survey for the control).

\section{Histological Observations}

To visualize where cultivable $S$. symbiotica strain is located in the plant, fluorescence in situ hybridization (FISH) was performed as previously described in (Ryuichi Koga, 2009; Caspi-Fluger et al., 2012). Visualization was performed on plants having 
undergone the same procedure as the watering experiment and the horizontal transmission test. Six fresh leaves and stems infested with cultivable $S$. symbiotica for 7 days by the watering experiments and twelve fresh leaves infested with the bacterium for 7 days by infected aphids of the transmission test were thinly sliced vertically with a sterile razor blade to recover part of the midrib. The samples were directly fixed in Carnoy solution at room temperature overnight. After fixation, specimens were bleached in alcoholic $6 \% \mathrm{H}_{2} \mathrm{O}_{2}$ solution for 2 days in complete darkness and then hybridized overnight in hybridization buffer containing the fluorescent probe $(10 \mathrm{pmol} / \mathrm{ml})$ : Cy3-PASSisR (5'-Cy3-CCCGACTTTATCGCTGGC-3') targeting 16S rRNA of S. symbiotica. After washing, stained samples were mounted in SlowFade antifade solution (Invitrogen), and observed under a Zeiss LSM 710 confocal microscope. Negatives controls consisted of uninfected leaves and stems and no-probe staining.

\section{Statistical Analyses}

The analysis aimed at identifying the effect of the cultivable S. symbiotica bacterium on the host plants. Plant functional traits were analyzed using general linear models (LM), after validation of the normal distribution, using condition (infected or uninfected plants) and survey (3 or 7 days of bacterial acquisition) as fixed factors. Statistical analyses were performed using the software R version 3.0.1 (R Core Team, 2014), using GrapheR package for graphics.

\section{RESULTS}

\section{Environmental Acquisition of Cultivable S. symbiotica}

The cultivable $S$. symbiotica strain can be transported from the soil infected with bacterial solution to $V$. faba plants [Figure 2 (1)]. After 3 days of exposure, the cultivable S. symbiotica was only detected in the leaves of plants (Table 1). The two pieces of leaf were infected in five out of six plants and one out of two leaf pieces was found to be infected in the other plant. After 7 days of exposure, the cultivable S. symbiotica was detected in both leaves and stems (Table 1). Leaves of four out of six plants were infected with the cultivable S. symbiotica. For one plant, two pieces of leaf were found infected and for the three other plants, only one piece of leaf was infected. In addition, stems of two out of six plants were infected. For these plants, one piece of stem was infected. Moreover, the cultivable S. symbiotica was not detected in the roots of plants (Table 1). For the control experiment, no part of plants was found to be infected with the bacteria (Table 1).

After 3 days, all plants had aphids infected by the cultivable S. symbiotica with an infection rate ranging from 22 to $75 \%$, depending on the host plants (Table 2). After 7 days of exposure, five out of six plants had aphids infected by the bacteria with an infection rate ranging from 14 to $57 \%$, depending on the host plants (Table 2). For the control experiment, no aphids were found infected with the cultivable S. symbiotica (Table 2). The cultivable $S$. symbiotica can thus be transferred from $V$. faba plants to the aphids, when bacteria were present only in the environment in direct contact with the roots [Figure $2(2)$ ].

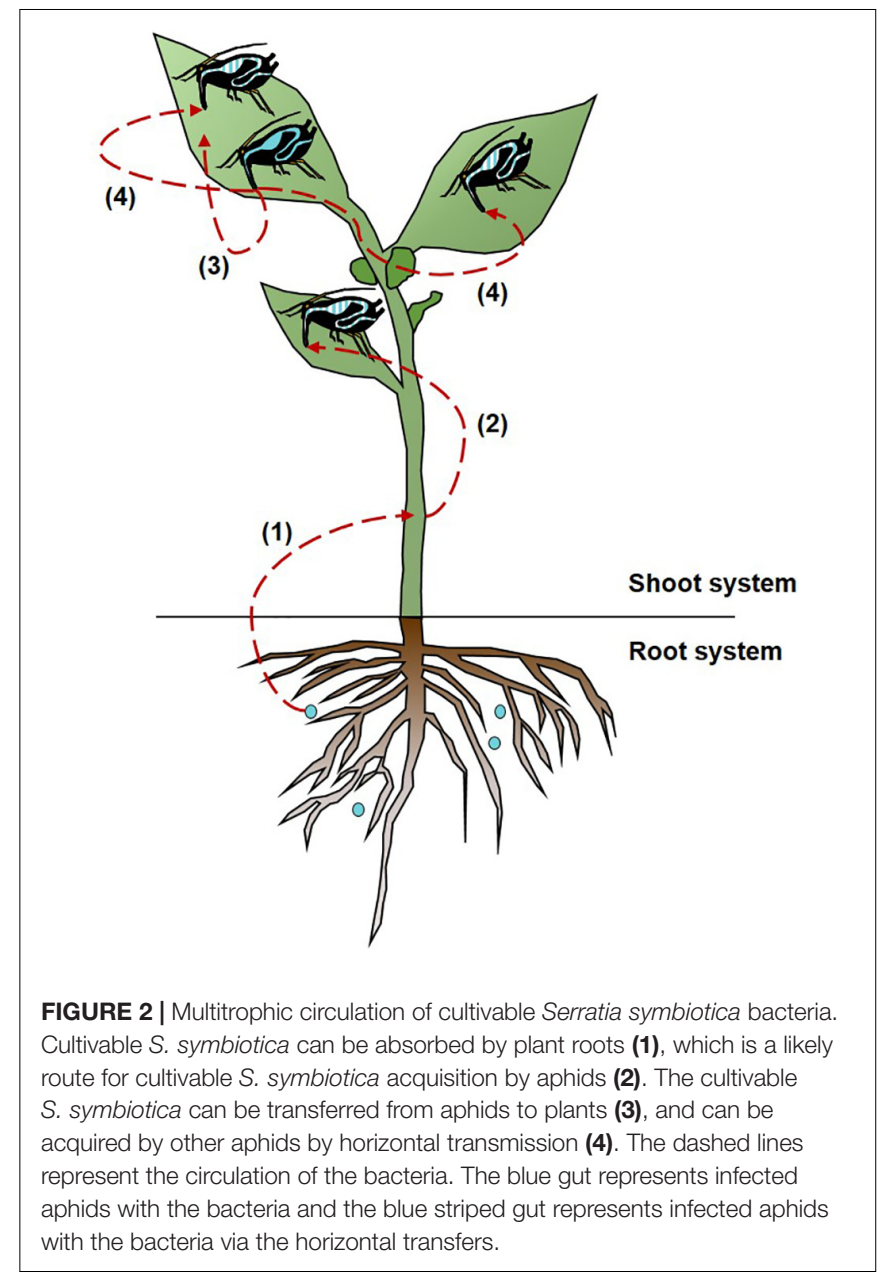

\section{Effect of Cultivable S. symbiotica on the Host Plant}

Eight plant functional traits were measured in order to investigate the biological effects of the cultivable S. symbiotica strain on plants. This strain had a significant effect on maximum shoot length of host plants (Tables 3, 4). Maximum shoot length was higher for plants infected with the cultivable $S$. symbiotica compared to uninfected plants (LM, $t=3.92, p=0.0016)$. The cultivable bacteria had no significant effects on total leaf dry mass and total leaf area of host plants, but the interaction between condition and survey had a significant effect on total leaf dry mass (Tables 3, 4). During the 3-day surveys, total leaf dry mass was higher for infected plants compared to uninfected plants, while the results were reversed after 7 -days. In addition, during the experiment, total leaf dry mass increased significantly for uninfected plants, while total leaf dry mass remained stable for infected plants (LM, $t=-2.46, p=0.028)$. The SLA $\left(\mathrm{cm}^{2} / \mathrm{g}\right)$ was significantly higher in 3-day surveys compared to 7-day surveys (LM, $t=-5.084, p<0.001$ ), however, the cultivable bacteria did not significantly affect this trait (Tables 3, 4), meaning that host plants developed new and smaller leaves. The cultivable $S$. symbiotica strain had no significant effect on the maximum root length. Nevertheless, S. symbiotica had a 
TABLE 1 | Environmental acquisition experiment of cultivable S. symbiotica by plants.

\begin{tabular}{|c|c|c|c|c|c|c|c|}
\hline $\begin{array}{l}\text { Duration } \\
\text { of Serratia } \\
\text { symbiotica } \\
\text { acquisition }\end{array}$ & Replicate & \multicolumn{6}{|c|}{ Number of infected plants by Serratia symbiotica } \\
\hline \multirow{6}{*}{3 days } & 2 & 2 & 2 & 2 & 0 & 2 & 0 \\
\hline & 3 & 2 & 1 & 2 & 0 & 2 & 0 \\
\hline & 4 & 2 & 2 & 2 & 0 & 2 & 0 \\
\hline & 6 & 2 & 2 & 2 & 0 & 2 & 0 \\
\hline & Control 1 & 2 & 0 & 2 & 0 & 2 & 0 \\
\hline & Control 2 & 2 & 0 & 2 & 0 & 2 & 0 \\
\hline \multirow[t]{4}{*}{7 days } & 1 & 2 & 0 & 2 & 0 & 2 & 0 \\
\hline & 2 & 2 & 2 & 2 & 0 & 2 & 0 \\
\hline & 3 & 2 & 1 & 2 & 1 & 2 & 0 \\
\hline & Control 2 & 2 & 0 & 2 & 0 & 2 & 0 \\
\hline
\end{tabular}

Cultivable S. symbiotica frequency in uninfected plants exposed to infected (treatment) or uninfected (control) solution. Three portions of each plant were analyzed: two pieces of leaves (one on each leaf), two pieces of stems and two pieces of roots. The duration of the bacterial acquisition was 3 and 7 days. The bold values correspond to replicates where aphids or plants were infected by the bacterium.

significant effect on total root dry mass and the SRL $(\mathrm{cm} / \mathrm{g})$ of host plants (Tables 3, 4). Total root dry mass was higher for plants infected with the cultivable S. symbiotica compared to

TABLE 2 | Environmental acquisition experiment of cultivable S. symbiotica by A. fabae aphids.

\begin{tabular}{|c|c|c|c|}
\hline $\begin{array}{l}\text { Duration } \\
\text { of Serratia } \\
\text { symbiotica } \\
\text { acquisition }\end{array}$ & Replicate & $\begin{array}{l}\text { Total number of } \\
\text { aphids tested }\end{array}$ & $\begin{array}{l}\text { Number of infected } \\
\text { aphids by Serratia } \\
\text { symbiotica } \\
\text { [infection rate (\%)] }\end{array}$ \\
\hline \multirow[t]{8}{*}{3 days } & 1 & 6 & $3(50)$ \\
\hline & 2 & 6 & $4(66.67)$ \\
\hline & 3 & 8 & $2(25)$ \\
\hline & 4 & 8 & $6(75)$ \\
\hline & 5 & 9 & $6(66.67)$ \\
\hline & 6 & 9 & 2 (22.22) \\
\hline & Control 1 & 6 & 0 \\
\hline & Control 2 & 6 & 0 \\
\hline \multirow[t]{8}{*}{7 days } & 1 & 6 & 2 (33.33) \\
\hline & 2 & 7 & $4(57.14)$ \\
\hline & 3 & 7 & $\mathbf{1}(14.29)$ \\
\hline & 4 & 6 & $3(50)$ \\
\hline & 5 & 8 & $2(25)$ \\
\hline & 6 & 6 & 0 \\
\hline & Control 1 & 8 & 0 \\
\hline & Control 2 & 5 & 0 \\
\hline
\end{tabular}

Cultivable S. symbiotica frequency in uninfected aphids exposed to infected (treatment) or uninfected (control) plants. The duration of the bacterial acquisition was 3 and 7 days. The bold values correspond to replicates where aphids or plants were infected by the bacterium. uninfected plants (LM, $t=2.38, p=0.031$ ). The SRL was lower for plants infected with the cultivable $S$. symbiotica compared to uninfected plants (LM, $t=-2.35, p=0.033$ ), signifying that the infected plants had developed more roots horizontally and/or the roots had a larger diameter than uninfected plants. The interaction between condition and survey had a significant effect on the root:shoot ratio of the host plants (Tables 3, 4). During the 3-day surveys, the ratio was the same for infected and uninfected plants, while during the 7-day surveys, the ratio was higher for infected plants than for uninfected plants, meaning that infected plants have allocated more energy into root growth than leaves, unlike uninfected plants. In addition, the root:shoot ratio decreased significantly for uninfected plants, whereas it increased for infected plants ( $\mathrm{LM}, t=2.44, p=0.029)$.

\section{Horizontal Transmission of Cultivable S. symbiotica}

A horizontal transmission of the cultivable $S$. symbiotica was observed in aphids located on the same plant [Figure 2 (4)]. After 3 days of acquisition, infected aphids by cultivable $S$. symbiotica were found on two out of four plants, with the infection rate varying between 20 and $67 \%$. After 7 days of acquisition, infected aphids were found on three out of four plants, with the infection rate varying between 20 and 60\% (Table 5). For the control experiments, no aphids were found to be infected with the bacteria (Table 5). Bacteria were also found in leaves of host plants: two out of three leaves were infected in each survey. For the control experiment, no plant leaf was found infected with the bacteria. These results suggest that (1) aphids are able to release bacteria in plants, (2) cultivable $S$. symbiotica strain can then move within the plants, and (3) can be acquired by previously uninfected aphids. 
TABLE 3 | Mean \pm Standard Error of eight functional traits of the host plant $V$. faba according to infection status.

\begin{tabular}{|c|c|c|c|c|}
\hline \multirow[t]{2}{*}{ Plant functional traits } & \multicolumn{2}{|c|}{ Control } & \multicolumn{2}{|c|}{ Bacterial solution } \\
\hline & 3 days & 7 days & 3 days & 7 days \\
\hline Maximum shoot length (cm) & $16.22 \pm 0.58$ & $16.18 \pm 0.51$ & $20.16 \pm 0.71$ & $19.56 \pm 0.56$ \\
\hline Maximum root length $(\mathrm{cm})$ & $17.67 \pm 0.86$ & $19.97 \pm 1.78$ & $19.79 \pm 0.75$ & $19.95 \pm 0.57$ \\
\hline Total leaf dry mass (g) & $0.09 \pm 0.01$ & $0.14 \pm 0.00$ & $0.12 \pm 0.01$ & $0.12 \pm 0.01$ \\
\hline Total leaf area $\left(\mathrm{cm}^{2}\right)$ & $27.72 \pm 4.07$ & $30.07 \pm 1.09$ & $41.14 \pm 3.58$ & $28.31 \pm 3.26$ \\
\hline Total root dry mass (g) & $0.21 \pm 0.04$ & $0.18 \pm 0.02$ & $0.25 \pm 0.02$ & $0.32 \pm 0.04$ \\
\hline $\mathrm{SLA}\left(\mathrm{cm}^{2} / \mathrm{g}\right)$ & $319.09 \pm 10.33$ & $208.55 \pm 7.40$ & $340.65 \pm 9.23$ & $226.04 \pm 14.61$ \\
\hline $\mathrm{SRL}(\mathrm{cm} / \mathrm{g})$ & $91.65 \pm 20.13$ & $112.34 \pm 12.14$ & $81.28 \pm 6.12$ & $67.94 \pm 9.20$ \\
\hline Root:shoot ratio & $2.58 \pm 0.76$ & $1.25 \pm 0.14$ & $2.10 \pm 0.17$ & $2.60 \pm 0.33$ \\
\hline
\end{tabular}

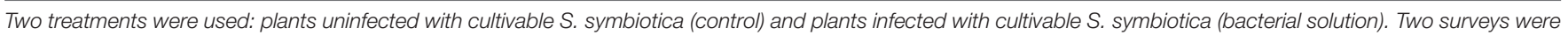
carried out: 3 and 7 days after inoculation.

TABLE 4 | General linear model results for the eight traits measured.

\begin{tabular}{|c|c|c|c|c|}
\hline Source of variation & d.f. & MS & $\boldsymbol{F}$ & $\boldsymbol{P}$ \\
\hline \multicolumn{5}{|c|}{ Maximum length of shoot $(\mathrm{cm})$} \\
\hline Condition & 1 & 53.58 & 26.49 & $<0.001$ \\
\hline Survey & 1 & 0.77 & 0.38 & 0.55 \\
\hline Condition*survey & 1 & 0.31 & 0.16 & 0.7 \\
\hline \multicolumn{5}{|c|}{ Maximum length of roots $(\mathrm{cm})$} \\
\hline Condition & 1 & 4.37 & 1.2 & 0.29 \\
\hline Survey & 1 & 3.43 & 0.96 & 0.34 \\
\hline Condition*survey & 1 & 4.58 & 1.28 & 0.28 \\
\hline \multicolumn{5}{|c|}{ Total dry mass of leaves (g) } \\
\hline Condition & 1 & 0.00017 & 0.37 & 0.55 \\
\hline Survey & 1 & 0.002 & 4.14 & 0.061 \\
\hline Condition*survey & 1 & 0.0029 & 6.038 & 0.028 \\
\hline \multicolumn{5}{|c|}{ Total leaves area $\left(\mathrm{cm}^{2}\right)$} \\
\hline Condition & 1 & 136.09 & 1.96 & 0.18 \\
\hline Survey & 1 & 271.52 & 3.91 & 0.067 \\
\hline Condition*survey & 1 & 230.41 & 3.98 & 0.066 \\
\hline \multicolumn{5}{|c|}{ Total dry mass of roots $(\mathrm{g})$} \\
\hline Condition & 1 & 0.033 & 5.96 & 0.029 \\
\hline Survey & 1 & 0.007 & 1.26 & 0.28 \\
\hline Condition*survey & 1 & 0.0099 & 1.78 & 0.2 \\
\hline \multicolumn{5}{|l|}{$\mathrm{SLA}\left(\mathrm{cm}^{2} / \mathrm{g}\right)$} \\
\hline Condition & 1 & 1525 & 2.15 & 0.16 \\
\hline Survey & 1 & 57718 & 81.39 & $<0.001$ \\
\hline Condition*survey & 1 & 17 & 0.023 & 0.88 \\
\hline \multicolumn{5}{|l|}{ SRL $(\mathrm{cm} / \mathrm{g})$} \\
\hline Condition & 1 & 2999.39 & 6.02 & 0.028 \\
\hline Survey & 1 & 17.98 & 0.036 & 0.85 \\
\hline Condition*survey & 1 & 1158.27 & 2.32 & 0.15 \\
\hline \multicolumn{5}{|l|}{ Root: shoot ratio } \\
\hline Condition & 1 & 0.76 & 1.38 & 0.26 \\
\hline Survey & 1 & 0.057 & 0.1 & 0.75 \\
\hline Condition*survey & 1 & 3.3 & 5.96 & 0.029 \\
\hline
\end{tabular}

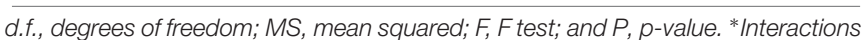
tested between two variables. The bold values correspond to significative $p$-value.

\section{Visualization of Cultivable S. symbiotica}

Once the presence of cultivable S. symbiotica in plants and aphids was determined, localization of the bacteria within plant
TABLE 5 | Horizontal transmission experiment of cultivable S. symbiotica to A. fabae aphids.

\begin{tabular}{lccc}
\hline $\begin{array}{l}\text { Duration of Serratia } \\
\text { symbiotica acquisition }\end{array}$ & Replicate & $\begin{array}{c}\text { Number of } \\
\text { exposed aphids }\end{array}$ & $\begin{array}{c}\text { Number of } \\
\text { infected aphids }\end{array}$ \\
\hline 3 days & Control 1 & 9 & 0 \\
& Control 2 & 10 & 0 \\
& Control 3 & 10 & 0 \\
1 & 13 & 0 \\
$\mathbf{7}$ days & 3 & 14 & 0 \\
& 3 & 10 & $\mathbf{2}$ \\
& 4 & 15 & $\mathbf{1 0}$ \\
& Control 1 & 6 & 0 \\
Control 2 & 7 & 0 \\
Control 3 & 9 & $\mathbf{2}$ \\
1 & 10 & $\mathbf{6}$ \\
2 & 10 & $\mathbf{3}$ \\
3 & 11 & 0
\end{tabular}

The cultivable S. symbiotica frequency found in uninfected aphids exposed to infected (treatment) or uninfected (control) aphids. The duration of the acquisition was 3 and 7 days. The bold values correspond to replicates where aphids or plants were infected by the bacterium.

tissues was investigated using a fluorescence in situ hybridization approach. For the environmental acquisition test, bacteria were found in five out of six leaves and three out of six stems of the infected plants, restricted to the phloem vessels, but not in any of the control leaves and stems (Figure 3). For the horizontal transmission test, bacteria were found in ten out of twelve leaves of the infected plants, also restricted to the phloem vessels, but not in the control leaves (Figure 4).

\section{DISCUSSION}

Much is known about aphids-plants (Goggin, 2007; Guerrieri and Digilio, 2008) and aphids-symbiotic bacteria (Oliver et al., 2014; Leclair et al., 2016) interactions, but understanding how aphids, plants and symbiotic bacteria interact together in nature remains largely elusive. It is established that the acquisition of 

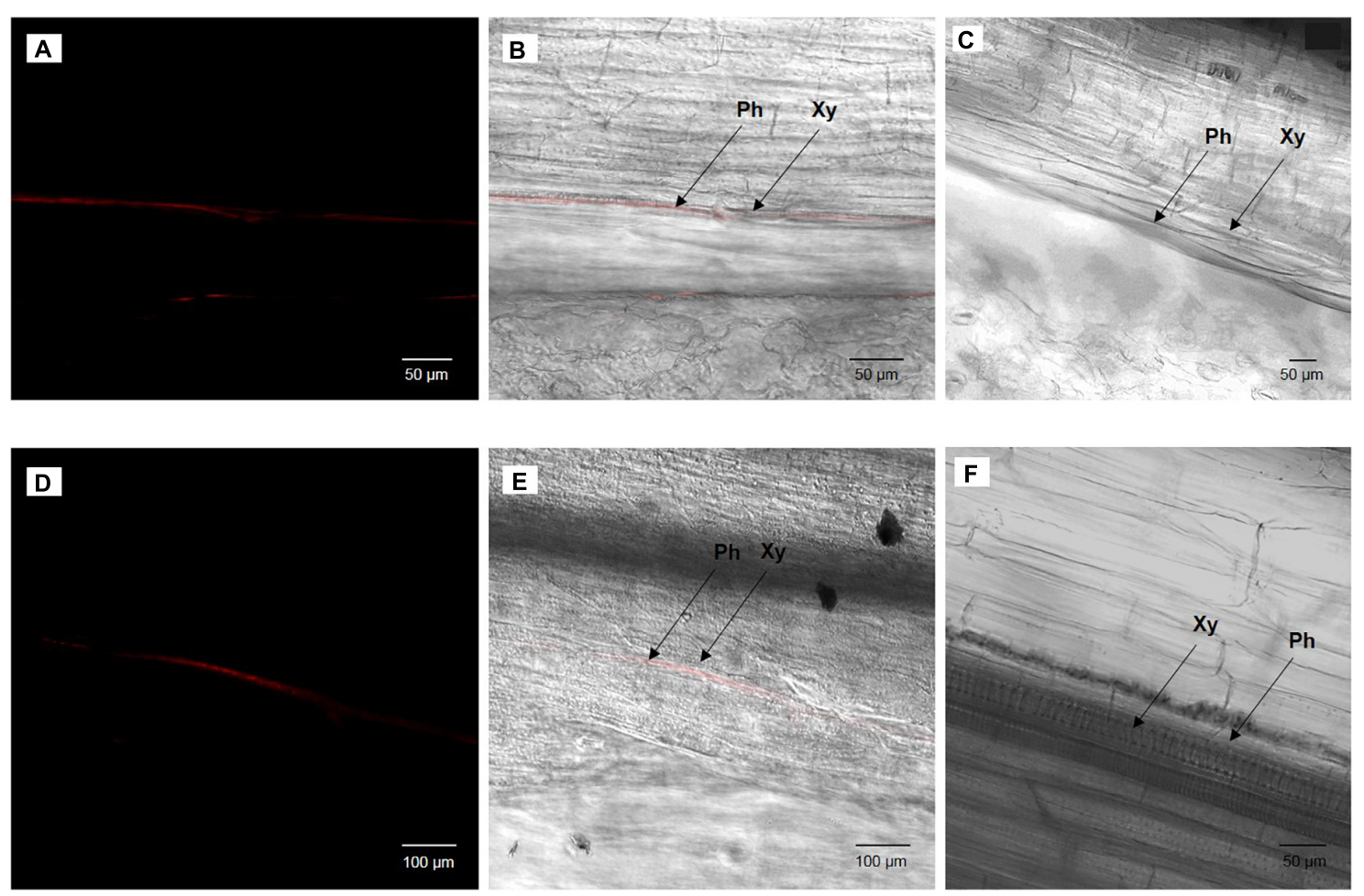

FIGURE 3 | Broad bean leaf (A,B) or stem (D,E) infected by cultivable S. symbiotica after the watering of plants with a bacterial solution and uninfected broad bean leaf $\mathbf{( C )}$ or stem $\mathbf{( F )}$ after the watering of plants with a PBS solution (negative control), visualized by fluorescence in situ hybridization. (A,D) S. symbiotica channel and (B,C,E,F) overlay of S. symbiotica on bright field channels. Red Cy3 signals correspond to S. symbiotica in phloem. Ph: phloem and Xy: xylem.
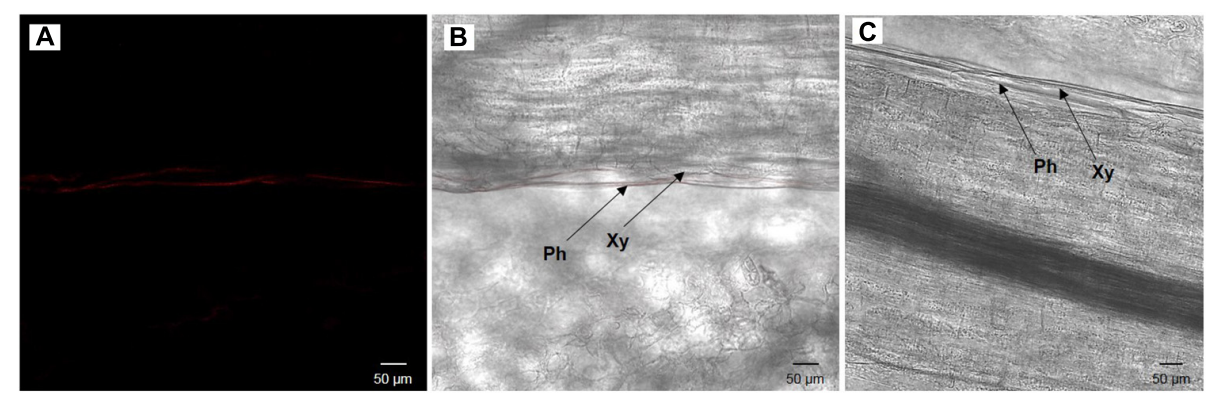

FIGURE 4 | Broad bean leaf infected by the cultivable S. symbiotica after the presence of infected aphids (A,B) and uninfected broad bean leaf inoculated with uninfected aphids (negative control, C), visualized by fluorescence in situ hybridization. (A) S. symbiotica channel and (B,C) overlay of S. symbiotica on bright field channels. Red Cy3 signals correspond to S. symbiotica in phloem. Ph: phloem and Xy: xylem.

environmental bacteria can have ecological and evolutionary impacts for hosts (Sugio et al., 2015). Our study clearly shows that the cultivable S. symbiotica having the possibility of freeliving lifestyle are capable of circulating from the soil to plants, as well as between plants and aphids (Figure 2). Our study also showed direct evidence of plant-mediated horizontal transmission of the cultivable S. symbiotica in aphid (Figure 2). Consequently, cultivable S. symbiotica horizontal transmission in aphids through plants is likely an important way by which these bacteria can spread in natural systems.

The oral route is one of the most common entry sites of bacteria into animals (Bright and Bulgheresi, 2010). We showed that cultivable S. symbiotica can enter the plants and then can be acquired by aphids through nutrition (Figure 2). These findings suggest that the bacteria may enter and move inside plant tissues, but the molecular mechanisms whereby plants acquire this cultivable strain are unknown. Since there is a vast microbial diversity in the soil environment (Garbeva et al., 2004), specific bacteria must be absorbed selectively and efficiently to pass the defenses of the plant roots (Bendix and Lewis, 2018). Indeed, in response to infection and to avoid pathogens, plants release biologically active compounds into the rhizosphere known to act as attractants or repellents to microbial soil communities (Baetz and Martinoia, 2014). Once in the plant sap containing 
a low amount of microorganisms (Jing et al., 2014), the cultivable S. symbiotica strain must thus overcome or resist plant defenses. Our FISH results suggest that the cultivable S. symbiotica can be found in phloem sap, which is why we first find a bacterial infection in the leaves and then in the stem. The cultivable S. symbiotica strain is probably passively transported by the xylem to the leaves where the bacteria will multiply and concentrate in the phloem that the aphid feed on. Indeed, unlike xylem sap, phloem sap is rich in sugar (Douglas, 2006; Bendix and Lewis, 2018) and is therefore a suitable environment for the development of the bacterium that needs sugar for its growth (Sabri et al., 2011). This would also explain why we do not find cultivable $S$. symbiotica in the plant roots. We suggest that the bacteria are passively transported in the roots and their low concentration does not allow to detect them. The cultivable S. symbiotica strain can be acquired by aphids during nutrition and end up in their gut with the sap where the niche is also interesting for them. Our hypothesis is that an evolutionary leap could have occurred in some of these strains localized in the aphid gut, passing the intestinal barrier of aphids and ending up in the hemolymph, a similar environment with high sugar content, but also proteins (Moriwaki et al., 2003). To establish a stable association, a loss of virulence and the diversion of function of the bacteria in favor of the aphid are needed. Environmentally generated infections could thus represent a reservoir of new beneficial traits for hosts creating a pathway toward new symbiotic associations (Clayton et al., 2012; Jousselin et al., 2013) and opens up new questions on the nature of the interaction between cultivable $S$. symbiotica and plants.

Plant-associated Serratia bacteria are found in various environments and plant species. When they are associated with plants, Serratia genus are generally referred as to endophytes, epiphytes or rhizobacteria able to enhance the growth of their host plant through a variety of mechanisms (Berg, 2000; Selvakumar et al., 2008). So far, the bacterium S. symbiotica has never been described as being associated with plant species, but has been depicted as an aphid symbionts (Oliver et al., 2010). Interestingly, our findings revealed that when the cultivable S. symbiotica was experimentally absorbed by plants, no disease symptoms were observed in plants, whereas the bacterium may modify the functioning of the plant, mainly at the root level. The presence of bacteria can promote root growth of plants (larger root diameter and/or lateral growth). The root:shoot ratio further showed that infected plants allocated more energy to root growth compared to uninfected plants. This could be explained by the production and/or induction of phytohormones by the cultivable S. symbiotica. For example, certain plant-associated strains of Serratia plymuthica and Serratia marcescens are known to produce IAA (indole-3-acetic acid) that is the most common plant hormone of the auxin class, which has positive effects on plant development (Ovadis et al., 2004; Shi et al., 2010). Additionally, a recent study showed that the genome of our cultivable strain encodes proteins potentially involved in invasion and biofilm formation (Renoz et al., 2017), such as the RNA polymerase sigma factor RpoS that has a regulatory role in biofilm development in some rhizobacteria (Petersen and Tisa, 2013). We also observed that presence of the bacteria promotes shoot growth of plants at length level but fosters less shoot biomass compared to uninfected plants. This is the first time that an aphid symbiont has been shown to have positive effects on the host plant, raising questions about a possible symbiotic association between this bacterium and plants. Therefore, further experiments focusing on the lifetime of the plant should be conducted to identify long-term effects, induced mechanisms, and the ability of bacteria to persist in plants.

Plant-mediated transmission of the symbiotic bacteria S. symbiotica in aphids has not been reported before. Several experimental studies already showed that plant sap can mediate horizontal transfers of facultative symbionts in phloem-feeding insects, such as Rickettsia in the whitefly Bemisia tabaci (CaspiFluger et al., 2012) and Cardinium in leafhoppers (Gonella et al., 2015). Here, we showed that cultivable S. symbiotica can be transferred from aphids to plants and subsequently acquired by other aphids (Figure 2). Unlike virus and bacteria into insect hemolymph that can invade the salivary glands and be injected into the plant phloem (Fereres and Raccah, 2015), we supposed that the cultivable $S$. symbiotica found in the aphid gut is merely ejected via the stylet into the plant phloem and then ingested during the feeding process. This result is in line with previous phylogenetic and trans-infection studies that suggested possibility of horizontal transfer of aphid symbiont between both phylogenetically close and distant species but that had never been demonstrated experimentally (Darby et al., 2001; Sandström et al., 2001; Darby and Douglas, 2003; Russell et al., 2003). Nevertheless, a study recently showed a possible horizontal transmission of the aphid endosymbiont Hamiltonella defensa mediated by plants ( $\mathrm{Li}$ et al., 2018). The difference is that the bacterium is endosymbiotic whereas our bacterial strain is localized in aphid gut, having a more direct contact with the environment. The study showed that the transfer was local on a single plant leaf and not in a systemic way as shown here. Moreover, uninfected aphids were only placed on an infected leaf in leaf cage (Li et al., 2018), which does not allow to determine if the transmission is carried out via plants and/or via infected honeydew as shown in (Darby and Douglas, 2003). In contrast, our study shows that the horizontal transmission is carried out via plant sap where the cultivable $S$. symbiotica circulate in the plant. Field studies showed that S. symbiotica bacteria are found in high occurrence in the European psyllid Cacopsylla pyri (Pons et al., in prep) and occur in other insects feeding on plant sap (Pons et al., in prep). These results suggest that plants could be an alternative for horizontal interspecific transmissions allowing bacteria to expand their host range and spread in natural insect lineages. In addition, these transfers could increase the possibility of gene exchange and recombination during insect-bacteria-plant interactions. Our results thus extend our understanding of transfer routes that symbiotic bacteria associated with aphids can take and provide explanations of how cultivable $S$. symbiotica is extracellularly transmitted through aphid generations (Pons et al., 2019).

Horizontal transmissions can have significant consequences for the ecology and evolution of symbiotic bacteria and their new hosts, and can be considered as a compensatory event to maintain insect symbiosis, preventing symbiont loss or replacing 
them in certain cases (Moran and Yun, 2015). This can be different with our model because horizontal transmission is not only an occasional transfer mode in addition to vertical transmission as observed in aphid endosymbionts (Chrostek et al., 2017) but it would be the main mode of transmission. In a recent study, we indeed showed that the cultivable $S$. symbiotica in aphid gut would be extracellularly transmitted across aphid generations (Pons et al., 2019). The host plant seems thus to be a good candidate for this type of transmission in insect feeding on plant sap. This is the case of the Burkholderia gut symbiont and the bean bug Riptortus pedestris model (Kikuchi and Fukatsu, 2014), where the beneficial bacterium is environmentally re-acquired every generation by nymphs at the gut level but the difference with our model is that Burkholderia is predominantly sequestered in bacterial crypts in specific regions of the insect gut, establishing a stable association. The result raises interesting questions relating to the evolution of cultivable S. symbiotica transmission route; specifically, will the bacteria remain strictly transmitted horizontally? Or are they likely to evolve toward vertical or mixed-mode transmission routes over the course of evolution?

Our results showed a decrease in infection rates in aphids during experiments. Indeed, during the environmental acquisition and horizontal transmission tests, the infection rate of aphids by the cultivable bacteria seemed to decline. However, for the horizontal transmission test, the number of plants with infected aphids increased. These results suggest that the ability to infect and establish associations of cultivable S. symbiotica with their newly acquired hosts would be low. If infection occurs randomly during feeding, it is expected that the bacterium will develop occasionally in aphids. Another study showed similar observations with the symbiont Cardinium in leafhoppers (Gonella et al., 2015). Successful bacterial acquisition can be due to the number of insects feeding on the host plant, the abundance of bacteria in the soil, the host plant and/or insects, but also due to plant mechanisms and environmental factors. Nevertheless, we detected some S. symbiotica bacteria in plants in the field where aphids infected by S. symbiotica were present (Pons et al., in prep) suggesting that aphids can release S. symbiotica into the plant and/or that the bacteria can be naturally present in the aphid environment (soil, plants). These field observations as well as our results of bacterial circulation and beneficial nature of the bacterium in plants suggest that the cultivable $S$. symbiotica would retain the ability to thrive in the environment where the potential aphid hosts prosper and that environmental generated infections could represent a reservoir for the emergence of new symbiotic associations in aphids and more widely in insects (Clayton et al., 2012; Hosokawa et al., 2016). In future studies, it will be interesting to test if the cultivable $S$. symbiotica can survive during its circulation, and if it is able to establish novel and persistent associations with aphids.

\section{CONCLUSION}

In conclusion, we investigated the ability of the cultivable S. symbiotica strain to circulate in aphid-host plant system.
Although in nature the system is much more complex, our results revealed that the cultivable $S$. symbiotica can enter the plants and induce new bacterial infections in aphids feeding on these new infected plants. We also found that the bacterium had positive effects on the host plant, mainly at the root level. Our results also demonstrated that cultivable S. symbiotica was horizontally transmitted between aphids across plant tissues, clearly showing that plants play a potential role in horizontal transfers of certain S. symbiotica strains between aphids. It is therefore possible to identify at least three routes of environmental inoculation of the cultivable S. symbiotica bacterium. First, infected aphids can transmit bacteria to the plant that can circulate through phloem sap and infect healthy aphids. The second possible route would start from the soil: bacteria can be naturally present and/or released from the aphid to the soil, e.g., through excrements, honeydew or cadavers. Returning to a free-living lifestyle, this can be an indirect way to colonize plants then aphids. Third, young nymphs seem able to be directly contaminated by ingesting honeydew from their infected mother just after birth (Pons et al., 2019). These results may have repercussions for our understanding of the evolutionary history of S. symbiotica bacterium and lead to questions about its origin. Indeed, the bacterium could be pre-adapted to develop in insects and may find an additional niche in plants and/or soil that can serve as acquisition and/or transmission routes. Alternatively, in view of our results on the beneficial nature of the cultivable $S$. symbiotica in the host plant, the bacterium could be pre-adapted to plants and/or soil and may evolve to use insects as alternative hosts (Perilla-Henao and Casteel, 2016). Our research therefore emphasizes the importance of considering symbiotic associations as a complex systems where microorganisms can circulate between different organisms in the trophic chain. Studying bacterium-aphid-plant interactions will allow a better understanding of the symbiotic bacteria lifestyle and how bacterial mutualism arise and spread in natural population.

\section{AUTHOR CONTRIBUTIONS}

IP designed the study, performed the laboratory work and data analysis, and wrote the manuscript. $\mathrm{CN}$ performed the laboratory work. FR and $\mathrm{TH}$ helped design the study and write the manuscript. All authors gave their final approval for publication.

\section{FUNDING}

This work was supported by the Fonds de la Recherche Scientifique (FNRS) through a Fonds pour la Recherche en Industrie et en Agronomie (FRIA) (FRIA Grant No. 1.E014.17F). The funders had no role in study design and analysis, decision to publish, or preparation of the manuscript. The funds received for open access publication fees are from our institution. 


\section{ACKNOWLEDGMENTS}

We thank Christoph Vorburger who supplied the A06-407 clone Aphis fabae used in our experiments. We also thank Marie-Christine Eloy for FISH assistance and the team of

\section{REFERENCES}

Abramoff, M. D., Magalhães, P. J., and Ram, S. J. (2004). Image processing with ImageJ. Biophotonics Int. 11, 36-42.

Aljanabi, S. M., and Martinez, I. (1997). Universal and rapid salt-extraction of high quality genomic DNA for PCR-based techniques. Nucleic Acids Res. 25, 4692-4693. doi: 10.1093/nar/25.22.4692

Altincicek, B., ter Braak, B., Laughton, A. M., Udekwu, K. I., and Gerardo, N. M. (2011). Escherichia coli K-12 pathogenicity in the pea aphid, Acyrthosiphon pisum, reveals reduced antibacterial defense in aphids. Dev. Comp. Immunol. 35, 1091-1097. doi: 10.1016/j.dci.2011.03.017

Baetz, U., and Martinoia, E. (2014). Root exudates: the hidden part of plant defense. Trends Plant Sci. 19, 90-98. doi: 10.1016/j.tplants.2013.11.006

Baumann, P. (2005). Biology of bacteriocyte-associated endosymbionts of plant sap-sucking insects. Annu. Rev. Microbiol. 59, 155-189. doi: 10.1146/annurev. micro.59.030804.121041

Bendix, C., and Lewis, J. D. (2018). The enemy within: phloem-limited pathogens. Mol. Plant Pathol. 19, 238-254. doi: 10.1111/mpp.12526

Berg, G. (2000). Diversity of antifungal and plant-associated Serratia plymuthica strains. J. Appl. Microbiol. 88, 952-960. doi: 10.1046/j.1365-2672.2000. 01064.x

Bright, M., and Bulgheresi, S. (2010). A complex journey: transmission of microbial symbionts. Nat. Rev. Microbiol. 8, 218-230. doi: 10.1038/nrmicro 2262

Buchner, P. (1965). Endosymbiosis of Animals with Plant Microorganisms. New York, NY: Interscience Publishers.

Burke, G., Fiehn, O., and Moran, N. (2009). Effects of facultative symbionts and heat stress on the metabolome of pea aphids. ISME J. 4, 242-252. doi: 10.1038/ ismej.2009.114

Cambier, V., Hance, T., and Hoffmann, E. D. (2001). Effects of 1,4-benzoxazin3-one derivatives from maize on survival and fecundity of Metopolophium dirhodum (Walker) on artificial diet. J. Chem. Ecol. 27, 359-370. doi: 10.1023/A: 1005636607138

Caspi-Fluger, A., Inbar, M., Mozes-Daube, N., Katzir, N., Portnoy, V., Belausov, E. et al. (2012). Horizontal transmission of the insect symbiont Rickettsia is plantmediated. Proc. R. Soc. Lond. B Biol. Sci. 279, 1791-1796. doi: 10.1098/rspb. 2011.2095

Chrostek, E., Pelz-Stelinski, K., Hurst, G. D. D., and Hughes, G. L. (2017). Horizontal transmission of intracellular insect symbionts via plants. Front. Microbiol. 8:2237. doi: 10.3389/fmicb.2017.02237

Clark, M. A., Moran, N. A., Baumann, P., and Wernegreen, J. J. (2000). Cospeciation between bacterial endosymbionts (Buchnera) and a recent radiation of aphids (Uroleucon) and pitfalls of testing for phylogenetic congruence. Evolution 54, 517-525. doi: 10.1111/j.0014-3820.2000.tb00054.x

Clayton, A. L., Oakeson, K. F., Gutin, M., Pontes, A., Dunn, D. M., von Niederhausern, A. C., et al. (2012). A novel human-infection-derived bacterium provides insights into the evolutionary origins of mutualistic insect-bacterial symbioses. PLoS Genet. 8:e1002990. doi: 10.1371/journal.pgen.1002990

Dale, C., and Moran, N. A. (2006). Molecular interactions between bacterial symbionts and their hosts. Cell 126, 453-465. doi: 10.1016/j.cell.2006. 07.014

Darby, A. C., Birkle, L. M., Turner, S. L., and Douglas, A. E. (2001). An aphid-borne bacterium allied to the secondary symbionts of whitefly. FEMS Microbiol. Ecol. 36, 43-50. doi: 10.1111/j.1574-6941.2001.tb00824.x

Darby, A. C., and Douglas, A. E. (2003). Elucidation of the transmission patterns of an insect-borne bacterium. Appl. Environ. Microbiol. 69, 4403-4407. doi: 10.1128/AEM.69.8.4403-4407.2003

Douglas, A. E. (1998). Nutritional interactions in insect-microbial symbioses: aphids and their symbiotic bacteria Buchnera. Annu. Rev. Entomol. 43, 17-37. doi: 10.1146/annurev.ento.43.1.17
Nicolas Schtickzelle for technical facilities. We are very grateful to Bertanne Visser and Florence Hecq for their helpful comments and corrections on the manuscript. This manuscript is publication BRC 433 of the Biodiversity Research Center (Universtité catholique de Louvain).

Douglas, A. E. (2006). Phloem-sap feeding by animals: problems and solutions. J. Exp. Bot. 57, 747-754. doi: 10.1093/jxb/erj067

Doyle, J. (1991). “DNA protocols for plants," in Molecular Techniques in Taxonomy NATO ASI Series, eds G. M. Hewitt, A. W. B. Johnston, and J. P. W. Young (Berlin: Springer), 283-293. doi: 10.1007/978-3-642-83962-7_18

Duron, O., and Hurst, G. D. (2013). Arthropods and inherited bacteria: from counting the symbionts to understanding how symbionts count. BMC Biol. 11:45. doi: 10.1186/1741-7007-11-45

Fereres, A., and Raccah, B. (eds). (2015). "Plant virus transmission by insects," in eLS, (Atlanta: American Cancer Society), 1-12. doi: 10.1002/9780470015902. a0000760.pub3

Frago, E., Dicke, M., and Godfray, H. C. J. (2012). Insect symbionts as hidden players in insect-plant interactions. Trends Ecol. Evol. 27, 705-711. doi: 10. 1016/j.tree.2012.08.013

Fukatsu, T., Nikoh, N., Kawai, R., and Koga, R. (2000). The secondary endosymbiotic bacterium of the pea aphid Acyrthosiphon pisum (Insecta: Homoptera). Appl. Environ. Microbiol. 66, 2748-2758. doi: 10.1128/AEM.66. 7.2748-2758.2000

Garbeva, P., van Veen, J. A., and van Elsas, J. D. (2004). MICROBIAL DIVERSITY IN SOIL: selection of microbial populations by plant and soil type and implications for disease suppressiveness. Annu. Rev. Phytopathol. 42, 243-270. doi: 10.1146/annurev.phyto.42.012604.135455

Gehrer, L., and Vorburger, C. (2012). Parasitoids as vectors of facultative bacterial endosymbionts in aphids. Biol. Lett. 8, 613-615. doi: 10.1098/rsbl.2012.0144

Goggin, F. L. (2007). Plant-aphid interactions: molecular and ecological perspectives. Curr. Opin. Plant Biol. 10, 399-408. doi: 10.1016/j.pbi.2007.06.004

Gonella, E., Pajoro, M., Marzorati, M., Crotti, E., Mandrioli, M., Pontini, M., et al. (2015). Plant-mediated interspecific horizontal transmission of an intracellular symbiont in insects. Sci. Rep. 5:15811. doi: 10.1038/srep15811

Gosalbes, M. J., Lamelas, A., Moya, A., and Latorre, A. (2008). The striking case of tryptophan provision in the cedar aphid Cinara cedri. J. Bacteriol. 190, 6026-6029. doi: 10.1128/JB.00525-08

Grigorescu, A. S., Renoz, F., Sabri, A., Foray, V., Hance, T., and Thonart, P. (2017). Accessing the hidden microbial diversity of aphids: an illustration of how culture-dependent methods can be used to decipher the insect microbiota. Microb. Ecol. 75, 1035-1048. doi: 10.1007/s00248-017-1092-x

Guerrieri, E., and Digilio, M. C. (2008). Aphid-plant interactions: a review. J. Plant Interact. 3, 223-232. doi: 10.1080/17429140802567173

Gündüz, E. A., and Douglas, A. E. (2009). Symbiotic bacteria enable insect to use a nutritionally inadequate diet. Proc. R. Soc. Lond. B Biol. Sci. 276, 987-991. doi: $10.1098 / \mathrm{rspb} .2008 .1476$

Henry, L. M., Maiden, M. C. J., Ferrari, J., and Godfray, H. C. J. (2015). Insect life history and the evolution of bacterial mutualism. Ecol. Lett. 18, 516-525. doi: 10.1111/ele.12425

Hosokawa, T., Ishii, Y., Nikoh, N., Fujie, M., Satoh, N., and Fukatsu, T. (2016). Obligate bacterial mutualists evolving from environmental bacteria in natural insect populations. Nat. Microbiol. 1:15011. doi: 10.1038/nmicrobiol.2015.11

Jing, X., Wong, A. C.-N., Chaston, J. M., Colvin, J., McKenzie, C. L., and Douglas, A. E. (2014). The bacterial communities in plant phloem-sap-feeding insects. Mol. Ecol. 23, 1433-1444. doi: 10.1111/mec.12637

Jousselin, E., Cœur, d'Acier, A., Vanlerberghe-Masutti, F., and Duron, O. (2013). Evolution and diversity of Arsenophonus endosymbionts in aphids. Mol. Ecol. 22, 260-270. doi: 10.1111/mec. 12092

Kearse, M., Moir, R., Wilson, A., Stones-Havas, S., Cheung, M., Sturrock, S., et al. (2012). Geneious Basic: an integrated and extendable desktop software platform for the organization and analysis of sequence data. Bioinformatics 28, 1647-1649. doi: 10.1093/bioinformatics/bts199

Kikuchi, Y., and Fukatsu, T. (2014). Live imaging of symbiosis: spatiotemporal infection dynamics of a GFP-labelled Burkholderia symbiont in the bean bug Riptortus pedestris. Mol. Ecol. 23, 1445-1456. doi: 10.1111/mec.12479 
Kikuchi, Y., Hosokawa, T., and Fukatsu, T. (2007). Insect-microbe mutualism without vertical transmission: a stinkbug acquires a beneficial gut symbiont from the environment every generation. Appl. Environ. Microbiol. 73, 43084316. doi: 10.1128/AEM.00067-07

Kraft, N. J. B., Godoy, O., and Levine, J. M. (2015). Plant functional traits and the multidimensional nature of species coexistence. Proc. Natl. Acad. Sci. U.S.A. 112, 797-802. doi: 10.1073/pnas.1413650112

Lamelas, A., Gosalbes, M. J., Manzano-Marín, A., Peretó, J., Moya, A., and Latorre, A. (2011). Serratia symbiotica from the aphid Cinara cedri: a missing link from facultative to obligate insect endosymbiont. PLoS Genet. 7:e1002357. doi: 10.1371/journal.pgen.1002357

Leclair, M., Pons, I., Mahéo, F., Morlière, S., Simon, J.-C., and Outreman, Y. (2016). Diversity in symbiont consortia in the pea aphid complex is associated with large phenotypic variation in the insect host. Evol. Ecol. 30, 925-941. doi: 10.1007/s10682-016-9856-1

Li, Q., Fan, J., Sun, J., Wang, M.-Q., and Chen, J. (2018). Plant-mediated horizontal transmission of Hamiltonella defensa in the wheat aphid Sitobion miscanthi. J. Agric. Food Chem. doi: 10.1021/acs.jafc.8b04828 [Epub ahead of print].

Manzano-Marín, A., Simon, J.-C., and Latorre, A. (2016). Reinventing the wheel and making it round again: evolutionary convergence in BuchneraSerratia symbiotic consortia between the distantly related lachninae aphids Tuberolachnus salignus and Cinara cedri. Genome Biol. Evol. 8, 1440-1458. doi: 10.1093/gbe/evw085

McFrederick, Q. S., Thomas, J. M., Neff, J. L., Vuong, H. Q., Russell, K. A., Hale, A. R., et al. (2017). Flowers and wild megachilid bees share microbes. Microb. Ecol. 73, 188-200. doi: 10.1007/s00248-016-0838-1

Montllor, C. B., Maxmen, A., and Purcell, A. H. (2002). Facultative bacterial endosymbionts benefit pea aphids Acyrthosiphon pisum under heat stress. Ecol. Entomol. 27, 189-195. doi: 10.1046/j.1365-2311.2002.00393.x

Moran, N. A., Munson, M. A., Baumann, P., and Ishikawa, H. (1993). A molecular clock in endosymbiotic bacteria is calibrated using the insect hosts. Proc. R. Soc. Lond. B Biol. Sci. 253, 167-171. doi: 10.1098/rspb.1993.0098

Moran, N. A., and Yun, Y. (2015). Experimental replacement of an obligate insect symbiont. Proc. Natl. Acad. Sci. U.S.A. 112, 2093-2096. doi: 10.1073/pnas. 1420037112

Moriwaki, N., Matsushita, K., Nishina, M., and Kono, Y. (2003). High concentrations of trehalose in aphid hemolymph. Appl. Entomol. Zool. 38, 241-248. doi: 10.1303/aez.2003.241

Nyholm, S. V., and McFall-Ngai, M. (2004). The winnowing: establishing the squid-vibrio symbiosis. Nat. Rev. Microbiol. 2, 632-642. doi: 10.1038/ nrmicro957

Oliver, K. M., Degnan, P. H., Burke, G. R., and Moran, N. A. (2010). Facultative symbionts in aphids and the horizontal transfer of ecologically important traits. Annu. Rev. Entomol. 55, 247-266. doi: 10.1146/annurev-ento-112408085305

Oliver, K. M., Russell, J. A., Moran, N. A., and Hunter, M. S. (2003). Facultative bacterial symbionts in aphids confer resistance to parasitic wasps. Proc. Natl. Acad. Sci. U.S.A. 100, 1803-1807. doi: 10.1073/pnas.0335320100

Oliver, K. M., Smith, A. H., and Russell, J. A. (2014). Defensive symbiosis in the real world - advancing ecological studies of heritable, protective bacteria in aphids and beyond. Funct. Ecol. 28, 341-355. doi: 10.1111/1365-2435. 12133

Ovadis, M., Liu, X., Gavriel, S., Ismailov, Z., Chet, I., and Chernin, L. (2004). The global regulator genes from biocontrol strain Serratia plymuthica IC1270: cloning, sequencing, and functional studies. J. Bacteriol. 186, 4986-4993. doi: 10.1128/JB.186.15.4986-4993.2004

Parmentier, E., and Michel, L. (2013). Boundary lines in symbiosis forms. Symbiosis 60, 1-5. doi: 10.1007/s13199-013-0236-0

Perilla-Henao, L. M., and Casteel, C. L. (2016). Vector-borne bacterial plant pathogens: interactions with hemipteran insects and plants. Front. Plant Sci. 7:1163. doi: $10.3389 /$ fpls.2016.01163

Petersen, L. M., and Tisa, L. S. (2013). Friend or foe? A review of the mechanisms that drive Serratia towards diverse lifestyles. Can. J. Microbiol. 59, 627-640. doi: 10.1139/cjm-2013-0343

Pons, I., Renoz, F., Noël, C., and Hance, T. (2019). New insights into the nature of symbiotic associations in aphids: infection process, biological effects and transmission mode of cultivable Serratia symbiotica bacteria. Appl. Environ. Microbiol. doi: 10.1128/AEM.02445-18 [Epub ahead of print].
R Core Team (2014). R: A Language and Environment for Statistical Computing. Vienna: R Foundation for Statistical Computing. Available at: http://www.Rproject.org/

Renoz, F., Champagne, A., Degand, H., Faber, A.-M., Morsomme, P., Foray, V., et al. (2017). Toward a better understanding of the mechanisms of symbiosis: a comprehensive proteome map of a nascent insect symbiont. PeerJ 5:e3291. doi: $10.7717 /$ peerj.3291

Renoz, F., Noël, C., Errachid, A., Foray, V., and Hance, T. (2015). Infection dynamic of symbiotic bacteria in the pea aphid Acyrthosiphon pisum gut and host immune response at the early steps in the infection process. PLoS One 10:e0122099. doi: 10.1371/journal.pone.0122099

Renoz, F., Pons, I., Vanderpoorten, A., Bataille, G., Noël, C., Foray, V., et al. (2018). Evidence for gut-associated Serratia symbiotica in wild aphids and ants provides new perspectives on the evolution of bacterial mutualism in insects. Microb. Ecol. doi: 10.1007/s00248-018-1265-2 [Epub ahead of print].

Russell, J. A., Latorre, A., Sabater-Muñoz, B., Moya, A., and Moran, N. A. (2003). Side-stepping secondary symbionts: widespread horizontal transfer across and beyond the Aphidoidea. Mol. Ecol. 12, 1061-1075. doi: 10.1046/j.1365-294X. 2003.01780.x

Ryuichi Koga, T. T. (2009). Quenching autofluorescence of insect tissues for in situ detection of endosymbionts. Appl. Entomol. Zool. 44, 281-291. doi: 10.1303/aez. 2009.281

Sabri, A., Leroy, P., Haubruge, E., Hance, T., Frère, I., Destain, J., et al. (2011). Isolation, pure culture and characterization of Serratia symbiotica sp. nov., the R-type of secondary endosymbiont of the black bean aphid Aphis fabae. Int. J. Syst. Evol. Microbiol. 61, 2081-2088. doi: 10.1099/ijs.0.02 4133-0

Salem, H., Florez, L., Gerardo, N., and Kaltenpoth, M. (2015). An out-of-body experience: the extracellular dimension for the transmission of mutualistic bacteria in insects. Proc. R. Soc. Lond. B Biol. Sci. 282:20142957. doi: 10.1098/ rspb.2014.2957

Sánchez, M. I., Pons, I., Martínez-Haro, M., Taggart, M. A., Lenormand, T., and Green, A. J. (2016). When parasites are good for health: cestode parasitism increases resistance to arsenic in brine shrimps. PLoS Pathog. 12:e1005459. doi: 10.1371/journal.ppat.1005459

Sandström, J. P., Russell, J. A., White, J. P., and Moran, N. A. (2001). Independent origins and horizontal transfer of bacterial symbionts of aphids. Mol. Ecol. 10, 217-228. doi: 10.1046/j.1365-294X.2001.01189.x

Scarborough, C. L., Ferrari, J., and Godfray, H. C. J. (2005). Aphid protected from pathogen by endosymbiont. Science 310, 1781-1781. doi: 10.1126/science. 1120180

Schultze, M., and Kondorosi, A. (1998). Regulation of symbiotic root nodule development. Annu. Rev. Genet. 32, 33-57. doi: 10.1146/annurev.genet. 32.1 .33

Selvakumar, G., Mohan, M., Kundu, S., Gupta, A. D., Joshi, P., Nazim, S., et al. (2008). Cold tolerance and plant growth promotion potential of Serratia marcescens strain SRM (MTCC 8708) isolated from flowers of summer squash (Cucurbita pepo). Lett. Appl. Microbiol. 46, 171-175. doi: 10.1111/j.1472-765X. 2007.02282.x

Shi, C.-L., Park, H.-B., Lee, J. S., Ryu, S., and Ryu, C.-M. (2010). Inhibition of primary roots and stimulation of lateral root development in Arabidopsis thaliana by the rhizobacterium Serratia marcescens 90-166 is through both auxin-dependent and -independent signaling pathways. Mol. Cells 29, 251-258. doi: 10.1007/s10059-010-0032-0

Simon, J.-C., Boutin, S., Tsuchida, T., Koga, R., Gallic, J.-F. L., Frantz, A., et al. (2011). Facultative symbiont infections affect aphid reproduction. PLoS One 6:e21831. doi: 10.1371/journal.pone.0021831

Snyder, A. K., Deberry, J. W., Runyen-Janecky, L., and Rio, R. V. M. (2010). Nutrient provisioning facilitates homeostasis between tsetse fly (Diptera: Glossinidae) symbionts. Proc. R. Soc. Lond. B Biol. Sci. 277, 2389-2397. doi: 10.1098/rspb.2010.0364

Sugio, A., Dubreuil, G., Giron, D., and Simon, J.-C. (2015). Plant-insect interactions under bacterial influence: ecological implications and underlying mechanisms. J. Exp. Bot. 66, 467-478. doi: 10.1093/jxb/ eru435

Tsuchida, T., Koga, R., Horikawa, M., Tsunoda, T., Maoka, T., Matsumoto, S., et al. (2010). Symbiotic bacterium modifies aphid body color. Science 330, 1102-1104. doi: 10.1126/science. 1195463 
Vigneron, A., Masson, F., Vallier, A., Balmand, S., Rey, M., Vincent-Monégat, C., et al. (2014). Insects recycle endosymbionts when the benefit is over. Curr. Biol. 24, 2267-2273. doi: 10.1016/j.cub.2014.07.065

Vorburger, C., and Gouskov, A. (2011). Only helpful when required: a longevity cost of harbouring defensive symbionts. J. Evol. Biol. 24, 1611-1617. doi: 10. $1111 / j .1420-9101.2011 .02292 . x$

Vorburger, C., Sandrock, C., Gouskov, A., Castañeda, L. E., and Ferrari, J. (2009). Genotypic variation and the role of defensive endosymbionts in an all-parthenogenetic host-parasitoid interaction. Evolution 63, 1439-1450. doi: $10.1111 / \mathrm{j} .1558-5646.2009 .00660 . \mathrm{x}$

Wernegreen, J. J. (2002). Genome evolution in bacterial endosymbionts of insects. Nat. Rev. Genet. 3, 850-861. doi: 10.1038/nrg931

Wright, I. J., and Westoby, M. (1999). Differences in seedling growth behaviour among species: trait correlations across species, and trait shifts along nutrient compared to rainfall gradients. J. Ecol. 87 , 85-97. doi: 10.1046/j.1365-2745. 1999.00330.x

Conflict of Interest Statement: The authors declare that the research was conducted in the absence of any commercial or financial relationships that could be construed as a potential conflict of interest.

Copyright (c) 2019 Pons, Renoz, Noël and Hance. This is an open-access article distributed under the terms of the Creative Commons Attribution License (CC BY). The use, distribution or reproduction in other forums is permitted, provided the original author(s) and the copyright owner(s) are credited and that the original publication in this journal is cited, in accordance with accepted academic practice. No use, distribution or reproduction is permitted which does not comply with these terms. 